\title{
EFISIENSI TEKNIS PERBANKAN SYARIAH DI INDONESIA
}

\author{
Hadi Rahadian \\ Fakultas Ekonomi Universitas Andalas \\ rahadian.hadi09@gmail.com
}

\begin{abstract}
This study analyzes the technical efficiency of Islamic banking at level I regions in Indonesia. The Stochastic Frontier method is used to obtain the efficiency value of Islamic Commercial Banks (BUS) and Sharia Business Units (UUS). The results showed that the efficiency of Islamic banks was still low with a value of 0.426. The highest efficiency was obtained by UUS in Riau Islands Province while the lowest score was obtained by BUS operating in West Papua Province. In general, UUS tends to be more technically efficient than BUS.
\end{abstract}

Keywords: efficiency, SFAS, Islamic banks

Abstrak : Penelitian ini menganalisis efisiensi teknis perbankan syariah di daerah tingkat I di Indonesia. Metode Stochastic Frontier digunakan untuk memperoleh nilai efisiensi Bank Umum Syariah (BUS) dan Unit Usaha Syariah (UUS). Hasil penelitian menunjukkan bahwa efisiensi bank syariah masih rendah dengan nilai 0,426. Efisiensi tertinggi diperoleh UUS di Provinsi Kepulaun Riau sedangkan nilai terendah diperoleh BUS yang beroperasi di Provinsi Papua Barat. Secara umum, UUS cenderung lebih efisien secara teknis dibandingkan BUS.

Kata Kunci: efisiensi, sfa, bank syariah

\section{A. Pendahuluan}

Secara umum perbankan syariah mengalami pertumbuhan yang signifikan pada aset, Dana Pihak Ketiga (DPK), dan pembiayaan dari tahun 2015 sampai 2019. Kenaikan aset terbesar terjadi pada periode 2016 yang mencapai $20,28 \%$. Hal yang sama juga berlaku untuk untuk DPK dan aset yang mencatat pertumbuhan tertinggi pada tahun 2016.

Tabel 1. Total Aset, DPK dan Pembiayaan (Dalam Miliar Rupiah)

\begin{tabular}{|l|c|c|c|c|c|}
\hline & $\mathbf{2 0 1 5}$ & $\mathbf{2 0 1 6}$ & $\mathbf{2 0 1 7}$ & $\mathbf{2 0 1 8}$ & $\mathbf{2 0 1 9}$ \\
\hline Aset & 304,001 & 365,661 & 435,021 & 489,688 & 538,322 \\
\hline DPK & 235,976 & 285,158 & 341,875 & 379,962 & 425,289 \\
\hline Pembiayaan & 218,761 & 254,669 & 293,458 & 329,277 & 365,125 \\
\hline
\end{tabular}

Sumber: Statistik Perbankan 2019

Kinerja perbankan syariah dapat dilihat dari nilai Non-Performing Financing (NPF) dan Financing-Deposit Ratio (FDR). NPF merupakan indikator untuk menilai pembiayaan yang macet sedangkan FDR sebagai ukuran perbandingan jumlah pembiyaan dengan DPK. NPF dan FDR tercatat mengalami penurunan selama periode 2015 sampai 2019. Turunnya nilai NPF berhubungan dengan rendahnya pembiayaan yang disalurkan oleh bank syariah.

Tabel 2. Kinerja Perbankan Syariah (Dalam Persentase)

\begin{tabular}{|l|r|r|r|r|r|}
\hline & \multicolumn{1}{|c|}{$\mathbf{2 0 1 5}$} & \multicolumn{1}{c|}{$\mathbf{2 0 1 6}$} & \multicolumn{1}{c|}{$\mathbf{2 0 1 7}$} & \multicolumn{1}{c|}{$\mathbf{2 0 1 8}$} & \multicolumn{1}{c|}{$\mathbf{2 0 1 9}$} \\
\hline NPF & 4.84 & 4.42 & 4.76 & 3.26 & 3.23 \\
\hline FDR & 88.03 & 85.99 & 79.61 & 78.53 & 77.91 \\
\hline
\end{tabular}

Sumber: Statistik Perbankan 2019 
Efisiensi perbankan syariah dapat dilihat dari rasio Biaya Operasional terhadap Pendapatan Operasional (BOPO).Biaya Operasional bank terdiri dari beban bagi hasil dana (deposito, giro, dan tabungan) yang harus dibayar ke nasabah, gaji karyawan, biaya umum dan administrasi. Pendapatan Operasional bank terdiri dari pendapatan dari pembiayaan dan pendapatan operasional non bagi hasil seperti jasa dan layanan perbankan (fee based income).Toleransi nilai BOPO ditetapkan OJK lebih rendah dari 75\% untuk bank BUKU 3 dan BUKU 4 dan lebih rendah dari 85\% untuk Bank BUKU 1 dan BUKU 2.Tabel 3 menampilkan nilai BOPO untuk BUS mengalami penurunan dari tahun 2015 sampai 2019 sedangkan untuk UUS nilai BOPO mengalami fluktuatif selama periode tersebut.

Tabel 3. Nilai BOPO Perbankan Syariah

\begin{tabular}{|l|r|c|c|c|c|}
\hline & \multicolumn{1}{|c|}{$\mathbf{2 0 1 5}$} & $\mathbf{2 0 1 6}$ & $\mathbf{2 0 1 7}$ & $\mathbf{2 0 1 8}$ & $\mathbf{2 0 1 9}$ \\
\hline BOPO BUS & 97.01 & 96.22 & 94.91 & 89.18 & 84.45 \\
\hline BOPO UUS & 83.41 & 82.85 & 74.15 & 75.38 & 78.01 \\
\hline
\end{tabular}

Sumber: Statistik Perbankan 2019

Terdapat tiga tipe bank syariah di Indonesia yaitu Bank Umum Syariah (BUS), Unit Usaha Syariah (UUS), dan Bank Pembiayaan Rakyat Syariah (BPRS).Tabel 3 menampilkan perkembangan jumlah bank syariah di Indonesia.Jumlah lembaga keuangan syariah berbentuk bank yang beropreasi di Indonesia pada 2019 sejumlah 198 bank yang terdiri dari 14 BUS. 20 UUS, dan 164 BPRS.

Tabel 4. Jumlah Bank Syariah

\begin{tabular}{|l|c|c|c|c|c|}
\hline & $\mathbf{2 0 1 5}$ & $\mathbf{2 0 1 6}$ & $\mathbf{2 0 1 7}$ & $\mathbf{2 0 1 8}$ & $\mathbf{2 0 1 9}$ \\
\hline Bank Umum Syariah (BUS) & 12 & 13 & 13 & 14 & 14 \\
\hline Unit Usaha Syariah (UUS) & 22 & 21 & 21 & 20 & 20 \\
\hline Bank Pembiayaan Rakyat Syariah (BPRS) & 163 & 166 & 167 & 167 & 164 \\
\hline
\end{tabular}

Sumber: Statistik Perbankan 2019

Pengukuran efisiensi bank syariah menjadi penting di tengah ketatnya persaingan di perbankan syariah dan perbankan nasional. Bank diharapkan beroperasi lebih efisiensi dibandingkan pesaingnya. Efisiensi akan berkaitan erat dengan tingkat keuntungan yang akan diperoleh bank dalam menyalurkan pembiyaan.

Penelitian tentang efisiensi bank syariah telah banyak dilakukan. Fokus penelitian yang lalu kebanyakan mengukur tingkat efisiensi masing-masing BUS dan UUS (Mohamad et al. (2006); Tahir dan Haron (2010); Beck, Demirguc-Kunt, \& Ouarda(2013);Hosen dan Rahmawati (2016)). Penelitian efisiensi perbankan syariah di setiap provinsi di Indonesia masih sangat terbatas. Padahal pengukuran efisiensi perbankan syariah di setiap wilayah dapat menjadi bahan evaluasi bagi manajemen bank. Bank dapat menemukan benchmarking untuk operasionalnya dengan cara mengetahui kantor cabang mana saja memiliki tingkat efisiensi yang tinggi. Walaupun nilai BOPO dapat menjadi acuan untuk efisiensi tetapi nilai tersebut tidak dapat menunjukkan hubungan input dan ouput.

Penelitian bertujuan untuk mengukur tingkat efisiensi teknis Bank Umum Syariah dan Unit Usaha Syariah di seluruh provinsi.Pengukuran efisiensi teknis merupakan hal yang krusial di tengah persaingan industri perbankan syariah dan konvensional. Hasil pengukuran bisa membantu pengambil keputusan untuk mengetahui inefisiensi perbankan syariah di setiap wilayah. 


\section{B. TINJAUAN LITERATUR Efisiensi}

Farel (1957) telah membahas konsep efisiensi dalam penelitiannya. Efisiensi dikelompokkan menjadi tiga yaitu alokatif, teknis, dan ekonomi. Efisiensi alokatif merupakan kemampuan unit pengambilan keputusan (bank) dalam memilih kombinasi input untuk menghasilkan output dengan meminimumkan biaya atau memaksimalkan keuntungan pada kondisi teknologi tertentu. Efisiensi teknis menunjukkan kemampuan relatif perusahaan dalam memproduksi output tertentu dengan menggunakan sejumlah input tertentu pada konidisi teknologi tertentu (Coelli, Rao, O'Donnell, \&Battese, 2005). Efisiensi ekonomi merupakan gabungan dari efisiensi alokatif dan efisiensi teknis. Sebuah perusahaan dapat memiliki efisiensi alokatif tetapi tidak efisien secara teknis begitu juga sebaliknya.

\section{Efisiensi Teknis}

Efisiensi teknis dapat berorientasi output atau input.Berorientasi output (OO) bermakna rencana produksi efisien secara jika tingkat output yang lebih tinggi dapat dicapai secara teknis dengan input yang ada. Orientasi input (OI) dalam efisiensi berarti bahwa tingkat output yang diamati dapat diproduksi dengan menggunakan input yang lebih sedikit (Kumbhakar, Wang, \& Horncastle, 2015).

\section{Gambar 1. Inefisiensi Teknis OI dan OO untuk Kasus Satu Input Satu Output}

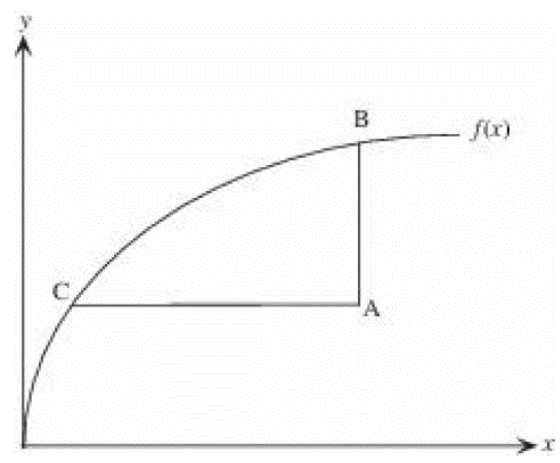

Pada Gambar 1 dapat dinyatakan bahwa estimasi inefisiensi tergantung pada teknologi yang diberikan (batas produksi). Kombinasi input-output mungkin tidak efisien untuk satu teknologi, tetapi dapat efisien pada teknologi yang berbeda. Implikasi untuk analisis empiris adalah ketika mengestimasi inefisiensi teknis dari produsen yang berbeda maka estimasi yang dilakukan seharusnya terkait dengan teknologi yang digunakan. Sebagai contoh, peneliti mengasumsikan petani padi di Jepang dan Indonesia memiliki teknologi produksi yang sangat berbeda. Estimasi efisiensi tidak dapat menggunakan fungsi produksi tunggal karena memunculkan hasil yang bias. Fungsi produksi seharusnya berbeda untuk negara yang memiliki teknologi yang berbeda.

Secara grafis, rencana produksi yang tidak efisien terletak di bawah batas produksi. Dalam gambar $1, \mathrm{f}(\mathrm{x})$ adalah batas (frontier) produksi, dan titik A adalah titik produksi yang tidak efisien. Ada dua cara untuk melihat mengapa itu tidak efisien. Cara pertama adalah melihat bahwa pada level input $\mathrm{x}$ saat ini, lebih banyak output dapat dihasilkan. Jarak AB tersebut menunjukkan kehilangan output karena inefisiensi teknis, dan membentuk dasar pengukuraninefisiensi teknis orientasi output.

Farel menjelaskan konsep efisiensi orientasi input dengan mengambil contoh perusahaan yang menggunakan 2 input (x1 dan $\mathrm{x} 2$ ) untuk memproduksi 1 output (y) dengan asumsi skala pengembalian konstan (Coelli, Rao, O'Donnell, \&Battese, 2005). Gambar 1 
merupakan ilustrasi isoquant unit perusahaan efisien penuh yang berada pada garis SS' (efisiensi teknis).

\section{Gambar 2. Efisiensi Teknis dan Alokatif}

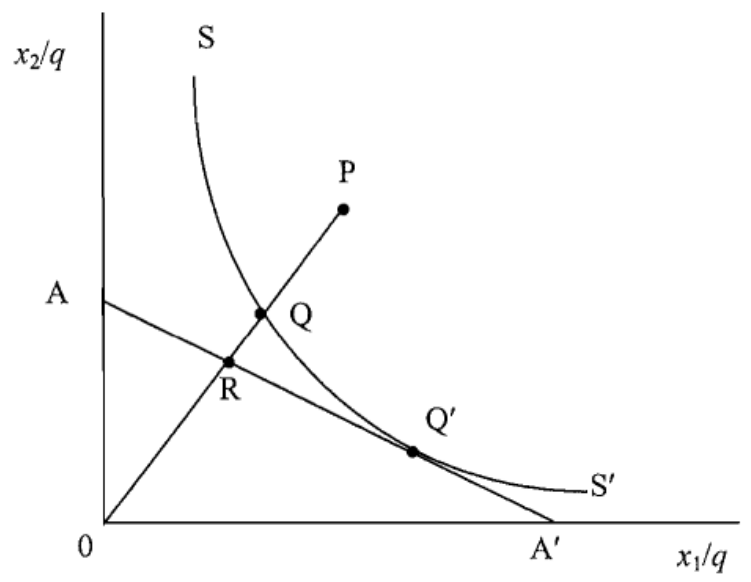

Inefisiensi teknis merupakan jarak QP dimana perusahaan menggunakan sejumlah input (P) untuk memproduksi satu unit output. Jarak QP adalah jumlah input yang dapat dikurangi secara proporsional tanpa pengurangan output. Pengukuran QP diekspresikan dalam persentase dari rasio QP/0P. Efisiensi teknis suatu perusahaan diukur dengan rasio

$$
\mathrm{TE}=0 \mathrm{Q} / 0 \mathrm{P}
$$

Yang sama dengan satu dikurang QP/0P. Nilainya antar nol dan satu yang menjadi indikator tingkat efisiensi teknis perusahaan. Nilai satu menunjukkan perusahaan mempunyai efisiensi teknis penuh yang pada gambar berada pada titik $\mathrm{Q}$.

Ukuran orientasi input efisiensi teknis perusahaan dapat dinyatakan dalam fungsi jarak input (input-distance function) di(x,q) sebagai:

$\mathrm{TE}=1 / \mathrm{di}(\mathrm{x}, \mathrm{q})$

Perusahaan dianggap efisien secara teknis jika berada pada frontiernya. Hal ini berarti nilai TE $=1$ sehingga di $(x, q)$ juga sama dengan 1 .

Coelli, Rao, O'Donnell, \&Battese (2005) menjelaskan konsep efisiensi orientasi output dengan mengambil contoh perusahaan yang menggunakan 2 input (x1 dan $\mathrm{x} 2)$ untuk memproduksi 1 output (y) dengan asumsi skala pengembalian konstan. Gambar 2 memberikan ilustrasi efisiensi teknis orientasi input. Gari ZZ' merupakan kurva kemungkinan produksi dengan titik A sebagai kondisi inefisiensi karena perusahaan beroperasi dibawah kurva ZZ'. Jarak AB mewakili inefiensi teknis orientasi output dapat ditulis sebagai berikut:

$$
\mathrm{TE}=0 \mathrm{~A} / 0 \mathrm{~B}=\mathrm{d} 0(\mathrm{x}, \mathrm{q})
$$

Dimana $\mathrm{d} 0(\mathrm{x}, \mathrm{q})$ merupakan fungsi jarak output dengan $\mathrm{x}$ sebagai vector input obsevasi dan $\mathrm{q}$ sebagai vector output observasi. 


\section{Gambar 3. Efisiensi Teknis Berorientasi Output}

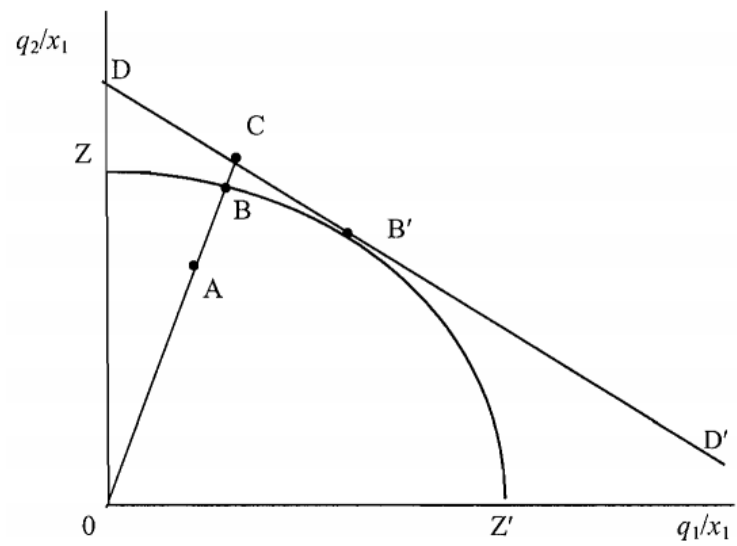

\section{Penelitian Terdahulu}

Mohamad et al. (2006) mengukur dan membandingkan efisiensi biaya dan keuntungan 80 bank di 21 negara Organisasi Konferensi Islam (OKI): terdiri dari 37 bank konvensional dan 43 bank Islam, menggunakan Data Envelopment Analysis (DEA). Selain itu, mereka menilai efisiensi bank-bank tersebut berdasarkan ukuran, usia, dan wilayah mereka. Temuan menunjukkan bahwa tidak ada perbedaan yang signifikan antara hasil efisiensi keseluruhan bank konvensional versus bank syariah. Hasil penelitian menunjukkan perbedaan signifikan dalam skor efisiensi rata-rata antara bank besar versus bank kecil dan bank baru versus bank lama di kedua perbankan. Ukuran dan usia tidak mempengaruhi kinerja bank.

Tahir dan Haron (2010) meneliti efisiensi biaya dan keuntungan bank-bank Islam di empat wilayah dunia: Afrika, Timur Jauh dan Asia Tengah, Eropa dan Timur Tengah selama periode 2003-2008. Penelitian ini didasarkan pada dasar tahunan dan regional menggunakan teknik stochastic frontier (SFA). Hasilnya menunjukkan bahwa efisiensi biaya dan laba telah meningkat selama periode tersebut dan bank syariah di keempat wilayah ini relatif lebih baik dalam mengendalikan biaya daripada menghasilkan laba. Bank syariah di Eropa relatif lebih hemat biaya dan keuntungan daripada kelompok bank lain. Bank-bank di kawasan Timur Tengah secara signifikan kurang efisien daripada bank-bank Islam di Afrika tetapi lebih efisien daripada bank-bank di Timur Jauh dan Asia Tengah.

Beck, Demirguc-Kunt, \& Ouarda(2013) menyelidiki dampak dari krisis global dan krisis perbankan lokal pada kinerja bank syariah dan bank konvensional dalam sampel yang beragam di 22 negara. Neraca digunakan untuk mengukur efisiensi seperti rasio biaya terhadap pendapatan, biaya overhead dan cadangan kerugian. Mereka melaporkan bahwa bank syariah kurang efisien daripada bank konvensional.

Firdaus \&Hosen (2013) mengukur efisiensi Bank Islam di Indonesia, menggunakan metode Data Envelopment Analysis. Objek penelitian ini adalah 10 (sepuluh) Bank Umum Syariah (BUS) di Indonesia. Periode data dimulai dari Triwulan kedua 2010 hingga Triwulan keempat 2012. Mereka menngemukakan bahwa tingkat efisiensi bank syariah di Indonesia selama periode waktu penelitian belum mencapai tingkat efisiensi yang optimal.

Hosen dan Rahmawati (2016) meneliti tingkat efisiensi dan profitabilitas di antara BankUmum Syariah di Indonesia. Hasil penelitian menunjukkan bahwa BMS adalah tingkat efisiensi terbesar di antara Bank Syariah di Indonesia yang mempengaruhi tingkat input dan output dari efisiensi BMS adalah biaya pegawai, biaya pembagian biaya, dan total pembiayaan yang dimiliki. Selain itu, hasil menunjukkan bahwa itu adalah tingkat profitabilitas terbesar yang faktor yang mempengaruhi profitabilitas BMS adalah rasio BOPO. Hasil penelitian juga menunjukkan bahwa BMI memiliki efisiensi yang rendah tetapi profitabilitas yang memadai. BMI memiliki efisiensi yang cukup dan profitabilitas yang tinggi, BMS memiliki efisiensi dan 
profitabilitas yang cukup, BRIS memiliki efisiensi dan profitabilitas yang rendah, dan BSB memiliki efisiensi tinggi dan profitabilitas yang rendah.

\section{METODOLOGI PENELITIAN \\ Desain Penelitian}

Studi longitudinal merupakan desain penelitian ini. Desain longitudinal memiliki sampel yang sama dari waktu ke waktu untuk melakukan pengamatan berulang. Penelitian menggunakan variabel yang sama untuk semua provinsi dengan periode penelitian dari tahun 2015 sampai 2019. Desain penelitian longitudinal menggambarkan pola perubahan dan membantu menetapkan arah dan besarnya hubungan sebab akibat. Pengukuran dilakukan pada setiap variabel selama dua atau lebih periode waktu yang berbeda. Peneliti dapat mengukur perubahan dalam variabel dari waktu ke waktu.

\section{Populasi dan Sampel}

Peneliti menggunakan data populasi untuk mengukur efisiensi teknis bank syariah. Populasi penelitian adalah daerah tingkat I di Indonesia yang berjumlah 33 provinsi dan luar negeri. Data Statistik Perbankan Syariah Desember 2016 sampai 2019 menunjukkan seluruh provinsi memiliki BUS dan sebagian memiliki UUS.

Data yang digunakan merupakan data panel.Keuntungan utama dari data panel dibandingkan data cross-sectionaldalam adalah memungkinkan pemodel memperhitungkan beberapa heterogenitas yang mungkin ada. Hal ini dapat dicapai dengan memperkenalkan efek individu yang tidak dapat diamati $\left(\alpha_{\mathrm{i}}\right)$ seperti invariant waktu dan spesifik individu.

\section{Teknik Pengumpulan Data}

Data variabel input dan output bersumber dari Statistik Perbankan Syariah Desember 2016 sampai Desember 2019 yang diterbitkan oleh OJK.Data bersifat tahunan dan nantinya diolah dengan perangkat lunak STATA. Semua nilai data berskala rasio sehingga dapat dilakukan operasional matematika.

\section{Variabel Penelitian dan Pengukuran Variabel}

Variabel yang digunakan terdiri dari variabel input dan output. Aset tetap dan aset keuangan merupakan variabel input. Jumlah pembiayaan yang disalurkan kepada nasabah merupakan variabel output. Tabel berikut menampilkan indikator dari seluruh variabel.

\section{Tabel 5. Variabel dan Indikator}

\begin{tabular}{|l|l|l|}
\hline Variabel & Indikator & Keterangan \\
\hline Output & Pembiayaan & $\begin{array}{l}\text { Pembiayaan Bagi Hasil, Piutang, } \\
\text { Pembiayaan Sewa (Ijarah), dan Salam }\end{array}$ \\
\hline Modal Fisik & Aset Tetap & $\begin{array}{l}\text { Penyusutan/Amortisasi dan Beban } \\
\text { Pemeliharaan Aset Tetap/Inventaris }\end{array}$ \\
\hline Modal Keuangan & Dana Pihak Ketiga & Total Dana Pihak Ketiga \\
\hline
\end{tabular}

\section{Analisis Data}

Analisis Efisiensi menggunakan metode Frontier Analysis. Metode ini mengukur tingkat efisiensi suatu unit usaha/negara/wilayah.Frontier Analysis memerlukan bentuk fungsidan metode estimasi untuk mendapatkan nilai efisiensi bank. Terdapat beberapa fungsi dan metode estimasi yang dapat digunakan. Penelitian ini menggunakan fungsi Cobb-Douglas dengan metode Estimasi Kemungkinan Maksimum (Maximum Likelihood Estimation).

a. Fungsi Cobb-Douglas

Fungsi produksi Cobb-Douglas diberikan oleh: 


$$
\begin{gathered}
y=f(x)=A \prod_{j=1}^{J} x_{j}^{\beta_{j}} \\
\ln y=\beta_{0}+\sum_{j} \beta_{j} \ln x_{j} \\
\operatorname{dimana} \beta_{0}=\ln A
\end{gathered}
$$

Dengan perubahan teknis, fungsi produksi CD dapat ditentukan sebagai:

$$
\ln y=\beta_{0}+\sum_{j} \beta_{j} \ln x_{j}+\beta_{t} t
$$

Model perbatasan produksi stokastik dengan inefisiensi teknis yang berorientasi output dapat dispesifikasikan sebagai berikut:

$$
\begin{aligned}
& \ln y_{i}=\ln y_{i}^{*}-u_{i}, \quad u_{i} \geq 0 \\
& \ln y_{i}^{*}=f\left(x_{i} ; \beta\right)+v_{i}
\end{aligned}
$$

di mana subskrip i menunjukkan observasi (perusahaan, individu, dan lain-lain), adalah skalar dari output yang diamati, $\mathrm{x}_{\mathrm{i}}$ adalah vektor $\mathrm{J} \times 1$ dari variabel input, $\beta$ adalah vector $\mathrm{J} \times 1$ dari vector koefisien yang sesuai, $\mathrm{v}_{\mathrm{i}}$ merupakan kesalahan acak rata-rata nol, dan $\mathrm{u}_{\mathrm{i}} \geq 0$ merupakan inefisiensi produksi.

Di sisi lain, model perbatasan produksi stokastik yang berorientasi output dapat dispesifikasikan sebagai:

$$
\ln y=\beta_{0}+\sum_{j} \beta_{j} \ln x_{j}-\left(\sum_{j} \beta_{j}\right) \eta
$$

yang pada dasarnya sama dengan model Orientasi Output dengan reparameterisasi:

$$
u=\left(\sum_{j} \beta_{j}\right) \eta
$$

\section{b. Estimasi Kemungkinan Maksimum (Maximum Likelihood Estimation/MLE)}

Estimasi Kemungkinan Maksimum menerapkan asumsi distribusi untuk erros statistik (vi) dan inefisiensi (ui) (Pit dan Lee, 1981). Fungsi kemungkinan dari suatu model diturunkan berdasarkan asumsi distribusi. Selanjutnya, parameter diestimasi dengan memaksimalkan fungsi loglikelihood. Akhirnya, inefisiensi dapat diperkirakan dengan menggunakan varian dari pendekatan JLMS (Kumbhakar, 1987). Nilai efisiensi diperoleh dengan rumus Battese dan Coelli (1988).

Untuk MLE, modelnya ditulis sebagai:

$$
\begin{gathered}
y_{i t}=f\left(x_{i t} ; \beta\right)+\epsilon_{i t}, \\
\epsilon_{i t}=v_{i t}-u_{i}, \\
v_{i t} \sim N\left(0, \sigma_{v}^{2}\right)
\end{gathered}
$$




$$
u_{i} \sim N^{+}\left(\mu, \sigma_{u}^{2}\right)
$$

Fungsi kemungkinan untuk observasi ke-i adalah (Pitt dan Lee, 1981; Kumbhakar dan Lovell, 2000):

$$
\begin{aligned}
\ln L_{i}= & \text { konstan }+\ln \Phi\left(\frac{\mu_{i *}}{\sigma_{*}}\right)+\frac{1}{2} \ln \left(\sigma_{*}^{2}\right)-\frac{1}{2}\left\{\frac{\Sigma_{t} \epsilon_{i t}^{2}}{\sigma_{v}^{2}}+\left(\frac{\mu}{\sigma_{u}}\right)^{2}-\left(\frac{\mu_{i *}}{\sigma_{*}}\right)^{2}\right\} \\
& -T \ln \left(\sigma_{v}\right)-\ln \left(\sigma_{u}\right)-\ln \Phi\left(\frac{\mu}{\sigma_{u}}\right),
\end{aligned}
$$

Dimana

$$
\begin{aligned}
& \mu_{i *}=\frac{\mu \sigma_{v}^{2}-\sigma_{u}^{2} \Sigma_{t} \epsilon_{i t}}{\sigma_{v}^{2}+T \sigma_{u}^{2}}, \\
& \sigma_{*}^{2}=\frac{\sigma_{v}^{2} \sigma_{u}^{2}}{\sigma_{v}^{2}+T \sigma_{u}^{2}},
\end{aligned}
$$

Fungsi log-likelihood dari model diperoleh dengan menjumlahkan In Li terhadap i, dimana $i=1,2,3, \ldots N$. Estimasi parameter dengan MLE diperoleh dengan memaksimalkan fungsi log-likelihood. Setelah estimasi parameter model, inefisiensi untuk setiap i dapat dihitung dari rata-rata atau modus (Kumbhakar dan Lovell, 2000) dengan menggunakan kedua formula berikut:

$$
E\left(u_{i} \mid \epsilon_{i}\right)=\mu_{i *}+\sigma_{*}\left[\frac{\phi\left(-\mu_{i *} / \sigma_{*}\right)}{1-\Phi\left(-\mu_{i *} / \sigma_{*}\right)}\right]
$$

$$
M\left(u_{i} \mid \epsilon_{i}\right)=\left\{\begin{array}{cc}
\mu_{i *} & \text { if } \mu_{i *} \geq 0 \\
0 & \text { lainnya }
\end{array}\right\}(1
$$

Persamaan 10 dan 11 merupakan estimator inefisiensi JLMS yang diperluas (Kumbhakar, 1987). Kedua persamaan di atas untuk distribusi setengah normal atau menjadikan $\mu$ sebagai fungsi variabel eksogen $\left(\mu=z_{i}^{\prime} \delta\right)$ untuk mengakomodasi faktor penentu inefisiensi. Kedua estimator inefisiensi konsisten disebabkan $T \rightarrow \infty$.

\section{HASIL DAN PEMBAHASAN}

Berdasarkan tabel di bawah, seluruh varibel independen (lnk, lnf dan yr) secara simultan memiliki pengaruh yang signifikan terhadap lny. Hal ini dibuktikan dengan semua nilai probabilitas chi kuadrat lebih kecil dari tingkat signifikansi sebesar 5\%. Variabel independen juga berpengaruh secara parsial terhadap variabel dependen. Koefisien yr sebesar 0,037 berimplikasi bahwa produktivitas rata-rata meningkat sebesar 3,7\% per tahun di seluruh provinsi selama periode 2016 sampai 2019. Dengan kata lain, rata-rata pembiayaan bank syariah mengalami kenaikan 3,7\% dari tahun 2016 sampai 2019.

Tabel 6. Hasil Estimasi dengan MLE

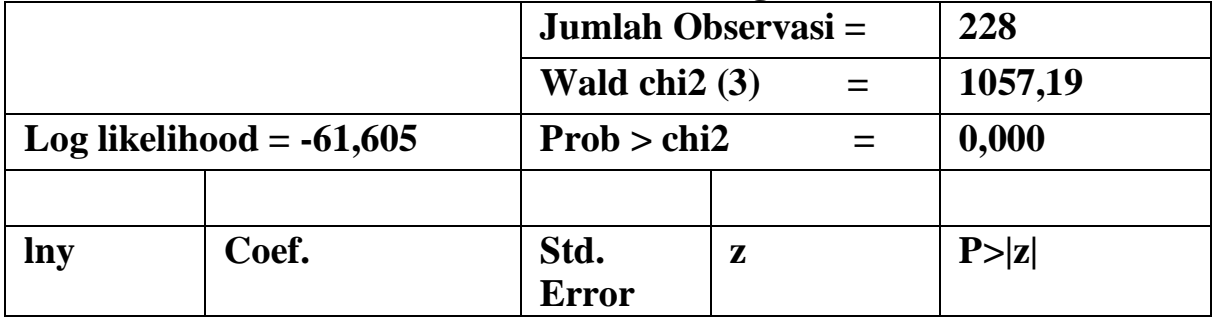




\begin{tabular}{|c|c|c|c|c|}
\hline frontier & & & & \\
\hline $\ln k$ & 0,581 & 0,079 & 7,33 & 0,000 \\
\hline Inf & 0,343 & 0,075 & 7,33 & 0,000 \\
\hline yr & 0,037 & 0,013 & 2,91 & 0,004 \\
\hline constant & 4,924 & 0,458 & 10,74 & 0,000 \\
\hline \multicolumn{5}{|l|}{$\mathbf{m u}$} \\
\hline iniStat & $-0,855$ & 0,164 & $-5,21$ & 0,000 \\
\hline Constant & 4,947 & 0,764 & 6,47 & 0,000 \\
\hline \multicolumn{5}{|l|}{ usigma } \\
\hline Constant & -1.651 & 0,243 & -6.79 & 0,000 \\
\hline \multicolumn{5}{|l|}{ vsigma } \\
\hline constant & $-3,322$ & 0,108 & -30.80 & 0,000 \\
\hline
\end{tabular}

Tabel 7 mengilustrasikan nilai estimasi efisiensi secara keseluruhan. Rata-rata nilai efisiensi teknis (variabel BC) adalah 0,426 yang berarti secara rata-rata bank syariah di 34 daerah tingkat 1 di Indonesia kehilangan potensi output sebesar 57,4\% yang disebabkan oleh inefisiensi teknis. Nilai maksimum sebesar 0,952 diperoleh UUS di Provinsi Kepulauan Riau sedangkan nilai minimum sebesar 0,077 dimiliki oleh BUS di Provinsi Papua Barat.

Tabel 7. Nilai Efisiensi Keselurahan

\begin{tabular}{|l|l|l|l|l|l|}
\hline Variabel & Observasi & Rata-rata & Standar Deviasi & Minimum & Maksimum \\
\hline BC & 228 & 0,426 & 0,301 & 0,077 & 0,952 \\
\hline
\end{tabular}

Nilai rata-rata efisiensi teknis UUS lebih tinggi dibandingkan BUS dengan selisih 0,679. Rendahnya nilai efisiensi BUS mengindikasikan bahwa persoalan efisiensi masih menjadi masalah utama bank syariah. Hal ini patut ditelusuri lebih lanjut mengingat bank syariah yang ideal berbentuk BUS.

Tabel 8. Nilai Efisiensi BUS dan UUS

\begin{tabular}{|l|l|l|l|l|}
\hline Jenis Bank Syariah & $\begin{array}{l}\text { Observas } \\
\text { i }\end{array}$ & Rata-rata Nilai Efisiensi & Minimum & Maksimum \\
\hline BUS & 136 & 0,093 & 0,077 & 0,144 \\
\hline UUS & 92 & 0,772 & 0,410 & 0,952 \\
\hline
\end{tabular}

\section{E. KESIMPULAN DAN SARAN}

\section{Kesimpulan}

Efisiensi teknis bank syariah baik BUS dan UUS masih tergolong rendah dengan nilai rata-rata 0,426 . Nilai efisiensi tertinggi sebesar 0,952 dimiliki UUS yang beroperasi di Provinsi 
Kepulauan Riau. Nilai efisiensi terendah dimiliki BUS yang berada pada Provinsi Papua Barat. UUS cenderung memiliki nilai efisiensi lebih tinggi dibandingkan BUS.

\section{Rekomendasi}

Rendahnya nilai efisiensi bank syariah mengindikasikan bahwa input yaitu aset tetap dan aset keuanganbelum optimal menghasilkan output(pembiayaan).Hal ini mengindikasikan adanya aset tetap (kantor, kendaraan, dan lainnya) yang belum dimanfaatkan secara optimal. Di sisi lain aset keuangan yang merupakan dana pihak ketiga (tabungan, giro, dan deposito) masih terkategori dana mahal sehingga nasabah cenderung tidak mengambil pembiayaan di bank syariah.

\section{F. DAFTAR PUSTAKA}

Anderson, David R., et al. (2014). Statistics for Business and Economics (12 ${ }^{\text {th }}$ ed). Mason: Cengage Learning.

Bader, Mohammed Khaled I., Mohamad, Shamsher., Ariff, Mohamed., and Shah, Taufiq Hassan. (2008) Cost, Revenue, and Profit Efficiency of Islamic versus Conventional Banks: International Evidence Using Data Envelopment Analysis. Islamic Economic Studies, 15 (2).

Beck, Thorsten, Demirguc-Kunt, Asli, \& Merrouche, Ouarda. (2013). Islamic vs. Conventional Banking: Business Model, Efficiency and Stability. Journal of Banking and Finance, 37 (2), $433-447$.

Coelli, T.J., Rao, D.S.P., O'Donnell, C.J., Battese, G.E. (2005). An Introduction to Efficiency and

Productivity Analysis $\left(2^{\text {nd }} e d\right)$. New York: Springer US.

Farrell, M. J. (1957). The Measurement of Productive Efficiency. Journal of the Royal Statistical Society, 120, 253-290.

Firdaus, Muhammad Faza., \&Hosen, Muhammad Nadratuzzaman. (2013). Efisiensi Bank Umum Syariah Menggunakan Pendekatan Two-Stage Data Envelopment Analysis. Buletin Ekonomi Moneter dan Perbankan.

Hosen, Muhammad Nadratuzzaman.,\& Rahwamati, Rafika Rahmawati. (2016). Efficiency and Profitability on Indonesian Islamic Banking Industry. Al-Iqtishad: Jurnal Ilmu Ekonomi Syariah (Journal of Islamic Economics), 8 (1), 33-48.

Kumbhakar, S. C. (1987). The Specification of Technical and Allocative Inefficiency in Stochastic Production and Profit Frontiers.Journal of Econometrics, 34, 335-48.

Kumbhakar, Subal C., Wang, Hung-Jen, \& Horncastle., Alan P. (2015). A Practitioner's Guide to Stochastic Frontier Analysis Using Stata. New York: Cambridge University Press.

Otoritas Jasa Keuangan (OJK) (2017, Februari). Statistik Perbankan Syariah Desember 2016

Otoritas Jasa Keuangan (OJK) (2018, Februari). Statistik Perbankan Syariah Desember 2017

Otoritas Jasa Keuangan (OJK) (2019, Februari). Statistik Perbankan Syariah Desember 2018

Otoritas Jasa Keuangan (OJK) (2020, Februari). Statistik Perbankan Syariah Desember 2019

Pitt, M. M., and Lee, L.-F. (1981). The Measurement and Sources of Technical Inefficiency in the Indonesian Weaving Industry.Journal of Development Economics, 9, 43-64.

Tahir, Izah Mohd., \&Haron, Sudin. (2010). Cost and Profit Efficiency of Islamic Banks: International Evidence Using Stochastic Frontier Approach.Banks and Bank Systems, $5(4)$. 